\title{
ACTIVE TOURISM DEVELOPMENT IN WESTERN UKRAINE
}

\author{
Mykhailo Hamkalo
}

\begin{abstract}
Active tourism is one of the most popular tourism types in Western Ukraine. It is facilitated by the diversity and attraction of natural resources as well as rich cultural and historical heritage. Western Ukraine consists of seven oblasts (regions): Volyn, Zakarpattia (Transcarpathia), Ivano-Frankivsk, Lviv, Rivne, Ternopil, Chernivtsi. Active tourism, especially hiking and skiing, began to develop within this area in the second half of the 19th century. This was facilitated by the emergence of numerous societies that specialized in active leisure promotion: Austrian Tourist Club, Polish Tatra Society, Czechoslovak Tourists Club, Chornohora and Plai. Environmental conditions and resources allow many kinds of active tourism, and considerable financial investments contribute to the emergence and development of ski resorts Bukovel, Plai, Dragobrat, Izki and others. The article analyzes the development of cave tourism; the main cave systems are described.
\end{abstract}

Keywords: active tourism, Western Ukraine, historical background, cave system

\section{Introduction}

Since the mid-19th century the territory of Western Ukraine was a place of vacationing and treatment for people from Austria-Hungary, and later from Poland and Czechoslovakia. Active tourism developed thanks to the creation of the Austrian Alpine Union (Osterreichischer Alpenverein), Austrian Tourist Club (Osterreichischer Tovristenclub) and Polish Tatra Society (Polske Towarzystwo Tatrzanskie), in particular, its departments within modern Ivano-Frankivsk Oblast: Stanislavskyi in Ivano-Frankivsk and Chornohora in Kolomyia. The main objectives of these departments were to organize hiking trips, to promote the development of mountain shelters chain and to mark routes.

\section{Historical background of active tourism development}

Highland of Ukrainian Carpathians - Chornohora mountain range was very popular among tourists which resulted in the tourism infrastructure development within this territory during 19-20 centuries. The first mountain shelter in Ukrainian Carpathians was established in 1878 in the tract of Hadzhyna in Chornohora. In 1904 Chornohora Department of PTS marked travel routes with coloured stripes for the first time. 
In the coming years, similar tourists centres were built in the tracts of Zarosliak at the foot of Mount Hoverla (1879) and Zavoiela in the valley Prut, mountain meadow Hropa (to the south-east of Mount Pip-Ivan-1883) and at the bottom of Mount Smotrych (1900). In the interwar period shelters in Chornohora were in more places: in the mountain meadow Maryshevska (since 1937.), on Yablunytskyi pass (since 1932), at the foot of Mount Kukol on the side of Vorokhta, on the range of Kostrych, and on the side of Zakarpattia - in the valleys Rohneska and Kvasivskyi Menchl, at the bottom of Mount Hutyn-Tomnatyk.

The lack of local lore and tourism activities negatively affected excursions and trips quality. Hiking was organized spontaneously, often without adequate prior scientific preparation. Local lore and tourist society "Plai" was established in 1924 in order to organize local lore and tourism activities. The society was engaged in local history research - collecting ethnographic descriptions, historical materials, analysis of the natural environment and resources, the results of which were used in designing and marking travel routes as well as mapping.

In addition to local lore and tourist society "Plai", society "Chornohora" acted in the researched area since 1910. In short time mountain shelters in mountain meadow Plistse, near mountains Grofa, Dovbushanka, Syvulia and the pass "Ryzhi" and "Stoly" were built thanks to the joint efforts of given societies. Tourist routes were marked in Chornohora and Gorgany. Regular staff (mountain keepers) which was responsible for the tourists' placement and escort, shelters maintenance, etc. was kept at the cost of membership due and donations.

The creation of Rakhiv department of Czechoslovak Tourists Club gave a considerable impetus for the active tourism development in what is now Zakarpattia oblast (the Transcarpathian region) in the 20th c. Its activity resulted in the creation of mountain shelters chain, in particular the construction of tourist shelter in the mountain meadow Menchul Kvasivskyi at an altitude of $1314 \mathrm{~m}$ above sea level. This facility operated since 1932 and provided accommodation for 50-60 people. At an altitude of $1200 \mathrm{~m}$ above sea level there was a tourist shelter "Wegerova Chata", which was situated in the house of the Carpathian mountain meadows Czech-Slovak Inspectorate. Several other mountain shelters on the ways to the main peaks of Chornohora range were created too (Quirini-Poplawski, 2006).

Seasonal (June 1-September 30) mountain shelter designed for 52 people started its work in 1932 in Rakhiv. At the foot of Chornohora in Bohdan village several mountain shelters of Czechoslovak Tourists Club were created: Rosenthaluv (4 seats), forestry (10 seats); in Luhy village at the confluence of Hoverla and Balzatul streams (13 seats). In 1935 a tourist shelter "Hoverla" (20 seats) was created, which was situated in the house of Delimitation Commission, at the bottom of Hoverla. In 1937, there were 61 centres with 475 beds, where tourists could stay overnight. Active work of Transcarpathian department of CTC is testified by the developed in 1928 jubilee Carpathian tourist path (route) $343 \mathrm{~km}$ 
long, which also included 22 marked side routes, the total length of which was about 1000 km (Quirini-Poplawski, 2006).

\section{Natural and recreational potential characteristic}

The area in question is characterized by remarkable biodiversity that is caused by considerable vertical drop from $101 \mathrm{~m}$ above sea level (Transcarpathian lowland) to $2061 \mathrm{~m}$ (Hoverla). Besides mountain ranges of Ukrainian Carpathians, Transcarpathian and Polesian lowlands, there are also Volyn and Podolian uplands. The area of the region is also crossed over by the main European watershed of the Black and Baltic Seas basins.

Ukrainian Carpathians are medium-height mountains and do not reach the snow line. Major elevations of summit plain are characteristic of Chornohora (2061 m), Marmarosha crystal massif (1946 m), Svydovets (1883 m), Gorgany (1836 m). Hardness and firmness of Marmarosha massif crystalline rocks caused highly dissected topography of this area with deep gorges, sharp ridges and peaks.

Ukrainian Carpathians are characterized by mild temperate continental climate. The distribution of heat and other climatic parameters (air pressure, precipitation, wind direction and strength) are determined primarily by the terrain. Carpathian Mountains stop cold air masses from the north, so the climate is formed predominantly by wet air masses from the Atlantic Ocean and continental air of temperate latitudes. Mountainous terrain enhances continental air. In the mountain part of the region there are the lowest average temperatures in January $\left(-8^{\circ} \ldots-6^{\circ}\right.$ C) and July $\left(+14^{\circ} \ldots+16^{\circ} \mathrm{C}\right)$. In Nyzhniy Studenyi village (Transcarpathian oblast) the absolute minimum temperature $-36^{\circ} \mathrm{C}$ is recorded [3, p.21].

The highest amount of precipitation (over $1400 \mathrm{~mm}$ ) falls in the highest part of Ukrainian Carpathians - Chornohora range. Precipitation falls mainly in summer, especially in June and July (over $60 \%$ of the annual rate). The most favourable period (under weather conditions) for hiking is August and September. The snow cover in the mountainous part of the region settles in mid-November, and thaws at the beginning of April-May.

Availability of altitudinal diversity is predetermined by temperature changes due to altitude. Thus, at an altitude of $613 \mathrm{~m}$ above sea level (Luhy weather station) average annual temperature is $5,4^{\circ} \mathrm{C}$ and at an altitude of $1429 \mathrm{~m}$ above sea level (Pozhyzhevska weather station) - it drops to $3.2^{\circ} \mathrm{C}$. Dangerous weather phenomena recorded in the researched area include: thunderstorms, strong winds and fogs. Chornohora range belongs to the territories of Ukrainian Carpathians and Ukraine as a whole which have the greatest number of days with thunderstorms. 45 thunderstorm days per year are recorded here. Thunderstorm activity begins in April, gets more intense in May, when the number of days with thunderstorms reaches eight, and is the most intense in July - up to 11 days; in August the number 
of such days is 7-9, in September - it gets considerably weaker, and in October and November thunderstorms are a very rare phenomenon (Hamkalo, Kudla, 2011).

Unlike most other types of tourism, hiking does not require relatively large material investments, as it develops in the existing natural environment and does not require significant investments in preparation and organization of tourist and sport events as well as construction of special facilities for their realization. Creation of favourable conditions for hiking is possible providing that there are clear high-quality route marking (labelling) and description, recreation facilities (campings). These tasks are dealt with by public community members ("Carpathian paths" Society) and experts of nature reserve fund.

Currently a chain of natural reserve fund sites is established within Ukrainian Carpathians: Carpathian Biosphere Reserve, "East Carpathians" Biosphere Reserve, "Gorgany" Nature reserve, Vyzhnytsya National Nature Park, "Synevyr" National Nature Park, "Skole Beskyd" National Nature Park, "Carpathian" National Nature Park. Within the flat part the following national parks stand out: Yavorivskyi, Prypiat-Stokhid.

In the Carpathian Biosphere Reserve one can find an extensive chain of ecotourism routes that are laid across the most interesting and attractive conservation areas, where a significant number of outstanding natural, cultural and historical objects is concentrated. The most popular environmental routes are: "Na Sokolyne Berdo" ("On the Falcon’s Nest"), "Kevekivskymy Pralisamy na Petros” ("Through Kevelivskyi Virgin Forests to Petros"), "Pralisamy Chornohory na Hoverlu" ("Through Chornohora Virgin Forests to Hoverla"). All routes are provided with information leaflets, stands and are marked in-situ (The Carpathian Biosphere Reserve, 2014).

The most popular category routes are mapped through Ukrainian Carpathian highlands and include: Chornohora, Svydovets, Marmarosha ranges and Gorgany. Such trips are designed for 6-8 days with the length of 120-160 km.

Ski tourism develops within such resorts: Slavske, Dragobrat, PylypetsPodobovets, Bukovel and others. Ski resort Bukovel is located near Polianytsya village (Ivano-Frankivsk oblast) at an altitude of 850-1372 $\mathrm{m}$ above sea level. The resort construction started in 2001 and in 10 years it has become one of the best resorts in Eastern Europe. The main factors that determined the choice of resort construction were: favourable location, unique climate conditions that prolong winter season. In 2012 the season finished on May, 9. The first tourists (about 10 thousand people) were received by the resort in 2002-2003 seasons. Currently there are 16 chairlifts serving, built-up infrastructure (hotels, multi-storey parking, restaurants, outfit rent, night clubs). Ski resort Bukovel has predominantly 4-chair lifts with a carrying capacity of 2400 persons per hour, which serve $55 \mathrm{~km}$ of trails of varying complexity on the slopes of five mountains: Dovha (1372 m), Bukovel, Bulchynokha, Babyn Pohar, Chorna Kleva. All runs are equipped with artificial snow spray, and three runs have fixed lighting. 
For 2013-2014 season there were 61 runs of all levels of difficulty prepared: 13 blue (easy for beginners), 41 red (average, for experienced skiers), 7 black (for sportsman and experts). The longest run is blue trail for beginners 5G (2106 m), which is located on the Chorna Kleva mountain, while the shortest run is run for experts 1B (296 m) - on Bukovel mountain. In 2012 Bukovel was voted as the world's fastest growing ski resort (Ski and Spa Resort Bukovel, 2014).

Ski resort Pylypets-Podobovets is situated at an altitude of $700 \mathrm{~m}$ above sea level in the villages of Pylypets and Podobovets of Mizhhirskyi district in Zakarpattia region. The resort is characterized by average transport accessibility, which is caused by the lack of direct railway connection, the nearest train station is Volovets, on a railway branch Kyiv-Lviv-Chop. There are six chairlifts in Pylypets, four on Mount Hymba (1491): a chair cableway 1650 m long, surface lifts 1500 m, 700, 300 m long, and two on Mount Magura: surface lifts 1000m and $800 \mathrm{~m}$. Chair lift on Mount Hymba is open all year round. In snowy winters the resort is known as the free-ride centre. The most popular resort runs are on Mount Hymba, over $20 \mathrm{~km}$ long, the longest among them has $2 \mathrm{~km}$; on Mount Zhyd Magura the longest run is $1500 \mathrm{~m}$ long. All runs are equipped with snow cats. No artificial snowmaking.

Ski resort Dragobrat is the highest in Ukraine. It is located on Svidovetsky range at an altitude of 1350-1704 m above sea level and surrounded by Blyznytsia $(1883 \mathrm{~m})$, Stig $(1707 \mathrm{~m})$ and Zhandarm $(1800 \mathrm{~m})$ mountains. The slopes of these mountains are used only when there are free-rides, which greatly increases the existing vertical drop within the resort and covers all existing segments of the ski resort. There is a seasonal snow cover starting from the height of $1400 \mathrm{~m}$ above sea level which appears in the second half of November and lies till the end of April.

The conducted analysis of tourist infrastructure revealed that within the ski resort Dragobrat hosting services were provided by 39 hotels and 4 private owners (2014). Most hotels are seasonal - they are open from December to May. Yasinia food and accommodation facilities are partially used too.

One of the main downsides of the resort is its poor transport accessibility, there are only two dirt roads that lead from Yasinia to the resort, 8 and $16 \mathrm{~km}$ long, and they are in unsatisfactory conditions. Transportation services are provided by off-roaders. The nearest settlement - Yasinia village has road and railway connection, the nearest international airport (Ivano-Frankivsk) - $120 \mathrm{~km}$ away. As a result of successfully implemented investment projects in Dragobrat resort for the last three years two chair cableways 1200 and 1500 meters long were built, existing surface lifts were upgraded, which greatly increased the capacity of the lifts.

As shown in Table 1, one of the main advantages of Dragobrat resort is its high mountain position, the upper chairlift station "Carpathian gull" is at an altitude of $1705 \mathrm{~m}$ above sea level, which has no analogues in height in Ukraine. High mountain location prolongs the ski season, owing to drop in average daily temperature with height $\left(0.5^{\circ} \mathrm{C}\right.$ per $\left.100 \mathrm{~m}\right)$ and increase in precipitation; 
availability of treeless slopes facilitates routing. Despite the lack of artificial snowmaking, the resort has the longest season - 150 days.

Dragobrat does not greatly differ from the existing ski resorts in Ukraine according its runs length and diversity. The maximum run length is $2080 \mathrm{~m}$. Vertical drop is the lowest among the researched resorts - $355 \mathrm{~m}$ (Table 1).

According to quantitative characteristics of the installed lifts, as well as their type (surface / chair) Bukovel ranks first (Table 2). Another important competitive advantage and mandatory component of the ski resort is providing medical assistance to injured at first-aid post. As one can see from Table 2, all analyzed resorts have first-aid posts, in most cases they are located at lower lift station. There is ski patrol on the slopes during winter season.

Table 1: Resorts main natural resources characteristics

\begin{tabular}{|l|c|c|c|c|c|}
\hline Resort & $\begin{array}{c}\text { The highest } \\
\text { lift station, } \\
\text { m above sea } \\
\text { level }\end{array}$ & $\begin{array}{c}\text { Maximum } \\
\text { run length, } \\
\mathrm{m}\end{array}$ & $\begin{array}{c}\text { Vertical } \\
\text { drop, m }\end{array}$ & $\begin{array}{c}\text { Average } \\
\text { season } \\
\text { duration, } \\
\text { days }\end{array}$ & Free-ride \\
\hline Dragobrat & 1705 & 2080 & 355 & 150 & + \\
\hline Bukovel & 1372 & 2106 & 513 & 150 & - \\
\hline Slavske & 1232 & 1700 & 340 & 120 & + \\
\hline $\begin{array}{l}\text { Pylypets- } \\
\text { Podobovets }\end{array}$ & 1160 & 2000 & 500 & 120 & + \\
\hline
\end{tabular}

Runs quality depends not only on the natural environment and resources, but also on the high-quality snow groomer vehicles (snowcats). We suggest a five-grade scale to assess the quality of snowcats. Daily work of snowcats on the slopes corresponds to 4-5 points, run ride once a week - 2-3 points, once a month - 1 point.

Table 2: Ski infrastructure characteristics

\begin{tabular}{|l|c|c|c|c|c|}
\hline \multirow{2}{*}{ Resort } & \multicolumn{2}{|c|}{ Lifts } & Snowmaking & $\begin{array}{c}\text { Quality of } \\
\text { snowcats }\end{array}$ & $\begin{array}{c}\text { First-aid } \\
\text { post }\end{array}$ \\
\cline { 2 - 3 } & surface & chair & - & 3 & + \\
\hline Dragobrat & 9 & 2 & - & 5 & + \\
\hline Bukovel & 1 & 15 & + & 1 & + \\
\hline Slavske & 16 & 3 & - & 2 & + \\
\hline $\begin{array}{l}\text { Pylypets- } \\
\text { Podobovets }\end{array}$ & 7 & 1 & - & & + \\
\hline
\end{tabular}

Considerable investments, developed infrastructure and new equipment determine high prices at Bukovel resort, in particular, ski lift day ticket in 20142015 season costs 22 euro. The cheapest price offers can be found in Zakarpattia oblast resorts - Pylypets and Dragobrat. 
Water tourism in Volyn and Rivne oblasts can be developed mainly within the Pripyat River basin. Besides Pripyat, Stokhid River, which fully flows in the Volyn oblast, is used in water tourism too. Rafting can be organized from April to October, the most difficult period is August-September, when there are the lowest water consumption figures. It is possible to start water routes from Lyubeshiv or Uhly villages, which are characterized by good transport accessibility.

Vyzhivka River is also suitable for rafting - kayaking can be organized within Lyubomylskyi, Starovyzhivskiy and Ratnivskyi districts starting from Ruda village. The river valley is up to $4 \mathrm{~km}$ wide, swampy floodplain. Meandering riverbed is 7-20 m wide, maximum depth - up to 3 meters, heavy-going in low water period.

Rafting down Turia River should start from Kovel, which is characterized by convenient transport connection (railway and road). Rafting duration is two to four days. Two-day rafting ends in Toikut (31 km), four-day - in Buzaky (77 km) (Kamin-Kashyrskyi district), where territorial highways can be found (T0311 and T0308).

Water tourism in the Carpathian region is organized on rivers: Prut, Dniester, Cheremosh, Black Tysa. Dniester - second largest river in Ukraine, rises in the north-eastern slopes of the Carpathians near Vovche village, Turka district, Lviv oblast. Catamaran tours and kayaking take place within Sambir and Staryi Sambir districts of Lviv oblast. Two canoeing routes are popular on Prut River: Vorokhta - Probiy waterfall - Yaremche (water-sports run, $30 \mathrm{~km}$ ) and water slalom run $(2 \mathrm{~km})$ near Yamna village. Most routes down Black Tysa start from Yasinia village in Rakhiv district, average complexity level, suitable for multiple rafting, close to a highway. The most popular rafting is along Black Cheremosh. Trips are designed for one to four days, during which the novice has an opportunity to master skills of single catamaran rafting and kayaking, overcoming the most difficult white-water (cataracts).

Cave tourism has undergone significant development due to the availability of caves of varying length, complexity and reclamation. Most of caves occur within Podolsko-Bukovinska Karst Region. The longest cave in Europe is Optymistychna (240,5 km). Ozerna, Mlynky, Crystal and others are also used in tourist purposes. These caves are located in Ternopil oblast (Table 3). The main organizers of cave tourism are Chortkiv Cavers Club and "Cyclop" Lviv Speleoclub.

In Ukrainian Carpathians the centre of cave tourism is UholskoShyrokoluzhansky forest reserve of the Carpathian Biosphere Reserve, which is situated within Tiachiv district, Zakarpattia oblast. There are more than 30 caverns in this area. Caves Uholky are diverse in their structure, length, depth, number of floors, type of stalactites. There is entrance to the largest cave of Ukrainian Carpathians called "Druzhba" in beech forest near the village of Small Uholka. In "Milk Stone" cave the scientists have discovered an ancient hunter site. In the tract 
“Chervenyi Kamin” ("Scarlet Stone"), near Neviya village a system of red caves is located. The deepest cave is "Syfon" (59 m.). Access to the cave and tour services is available in the Carpathian Biosphere Reserve.

Table 3: Podolia-Bukovyna karstland main caves characteristic

\begin{tabular}{|c|l|c|c|}
\hline & \multicolumn{1}{|c|}{ Name } & Total length, $\mathrm{km}$ & Number of levels \\
\hline 1 & Optymistychna & 240,5 & 3 \\
\hline 2 & Ozerna & 134 & 3 \\
\hline 3 & Cinderella & 91 & 3 \\
\hline 4 & Mlynky & 44,7 & 1 \\
\hline 5 & Crystal & 23 & 1 \\
\hline 6 & Slavka & 9,1 & 1 \\
\hline
\end{tabular}

Source: Khovalko (2013)

\section{Conclusion}

Western Ukraine active tourism development is possible only after upgrading tourist infrastructure and creating new hospitality places of world recognized standards. The significant number of tourist routs is of poor condition and in vital need of renovation. Growing demand for hiking requires: camping sites, equipment rentals, shelters along the existing tourist routes and marking new ones. In general, available natural resources potential promotes ski tourism, but there are some disadvantages in mountain areas such as frequent unfavourable weather conditions (wind storm, intense snowfalls, etc.). This causes damage to power lines, lifts shutdown in low visibility conditions, etc., absence of great waterways that can be used as a resource for run artificial snowmaking.

\section{References}

HAMKALO, M. - KUDLA, N. 2011. Karpaty Ukrainskie jako region turystyczny - uwarunkowania i mozliwosci rozwoju. Prace geograficzne, zeszyt 125. Instytut Geografii i Gospodarki Przestrzennej UJ. Krakow, 2011. s. 63-75.

KHOVALKO, A. 2013. Tourist and recreational zones of the spelaen region of

Podillya assessment. ISSN 2078-6441. Scientific journal of the Lviv University. Series geogr. 2013. Issue 43. p. 99-107.

NESTERUK, YU. Plant World of the Ukrainian Carpathians: Chornohora. Ecology travels. Lviv: BaK, 2003. 520 p.

QUIRINI-POPLAWSKI, R. 2006. Zarys historii zagospodarowania turystycznego

Czarnohory w Karpatach Ukrainskich. Czarnogora. Pryroda i chlowiek. Krakow, 2006, s. 185-202.

SKI AND SPA RESORT BUKOVEL. http://bukovel.com/ [cit. 2014.09.20]. 
THE CARPATHIAN BIOSPHERE RESERVE. www.cbr.nature.org.ua/ [cit. 2014.09.20]

Mykhailo Hamkalo, PhD., Associate professor

Department of Tourism, Faculty of Geography

Ivan Franko National University of Lviv

St. Doroshenko 41, 79000, Lviv

E-mail: hamkalo.m@gmail.com 